\title{
Gereja Profetik Menurut Paulo Freire
}

\author{
Merensiana Hale ${ }^{1 *}$, Franklin Ton ${ }^{2}$ \\ ${ }^{1,2}$ Fakultas Teologi, Universitas Kristen Artha Wacana \\ *merenslao0@gmail.com
}

\section{D0I: https://doi.org/10.34307/b.v4i1.234}

\begin{abstract}
This paper aims to elaborate Paulo Freire's thoughts on the prophetic church and its relevance for the church today. The method used to achieve the goal is library research. In particular, it is focused on the thoughts of one educational figure, Paulo Freire, who contributed to his thoughts on liberation education by the church in the prophetic church concept. The conclusion of this paper is that education in the church is an important means of bringing about change in society. Consientization by the church is carried out in the spirit of raising the critical awareness of the congregation.
\end{abstract}

Keywords: The Church that is Prophetic, Consientization, Paulo Freire

\begin{abstract}
Abstrak: Tulisan ini bertujuan untuk mengelaborasi pemikiran Paulo Freire tentang gereja yang profetik dan relevansinya bagi gereja masa kini. Metode yang digunakan untuk mencapai tujuan adalah penelitian kepustakaan (library research). Secara khusus difokuskan pada pemikiran salah satu tokoh pendidikan, Paulo Freire, yang memberi sumbangan pemikiran mengenai pendidikan pembebasan oleh gereja dalam konsep gereja yang profetik. Kesimpulan tulisan ini adalah pendidikan dalam gereja merupakan sarana penting dalam mewujudkan perubahan dalam masyarakat. Konsientisasi oleh gereja dilakukan dengan semangat menumbuhkan kesadaran kritis jemaat.
\end{abstract}

Kata kunci: Gereja yang Profetik, Konsientisasi, Paulo Freire

\begin{tabular}{llll}
\hline Article History & Received: 13-02-2021 & Revised: 13-06-2021 & Accepted: 16-06-2021
\end{tabular}

\section{Pendahuluan}

Gereja dalam keberadaannya di dunia tidak terlepas dari perjumpaan dengan persoalanpersoalan dalam konteks di mana gereja itu berada. Persoalan ketidakadilan dalam balutan penindasan menjadi bagian yang dihadapi gereja. Apapun bentuk dan namanya realitas yang demikian adalah gambaran yang jauh dari tanda-tanda kerajaan Allah. Ketidakadilan adalah realitas yang memberi dampak pada seluruh kehidupan masyarakat. Ketidakadilan selalu memberi masalah-masalah lanjutan dalam kehidupan bermasyarakat. Seperti pembatasan hak, yang berdampak pula bagi kemiskinan. Dalam 
realitas yang demikian idiologi yang berkembang adalah idiologi yang selalu menguntungkan penguasa. Sedangkan masyarakat lemah terbenam dalam kebudayaan bisu. Idiologi yang dominan selalu mempengaruhi seluruh tatanan kehidupan masyarakat. Sebagai milik Allah, gereja berkewajiban menyatakan kehendak Allah dalam realitas yang demikian. Di mana Allah diimani sebagai pembebas, demikianlah gereja memperjuangkan kebebasan bagi seluruh umat.

Berkaitan dengan hal tersebut, salah satu tokoh pendidikan, Paulo Freire, memberi sumbangan bagi gereja lewat pemikirannya mengenai pendidikan pembebasan oleh gereja dalam konsep gereja yang profetik. Gereja yang profetik memperjuangkan pembebasan lewat upaya menumbuhkan kesadaran kritis atau konsientisasi. Tulisan ini menekankan pada relevansi pemikiran Freire bagi konteks gereja masa kini untuk merumuskan praksis-praksis pembebasan, dalam memenuhi tugas dan tanggungjawabnya sebagai milik Allah.

Penekanan tulisan ini menjadi penting sebab sudah ada banyak tulisan terkait pemikiran Paulo Freire. Beberapa kajian tulisan tersebut sebagai berikut: Abdillah, mengulas Teori dehumanisasi pendidikan menurut Paulo Freire menggunakan perspektif filsafat. Dehumanisasi pendidikan yang dimaksudkan oleh Paulo Freire adalah pendidikan yang malah menjauhkan manusia dari eksistensinya sebagai manusia yang harusnya berpikir bebas dan kritis. ${ }^{1}$ Terkait berpikir kritis ini, Rohinah menjelaskan upaya perjuangan pendidikan oleh Paulo Freire menuju sebuah perubahan nyata agar pendidikan tidak hanya sekedar mempersiapkan robot-robot mekanik masa depan melainkan mampu melahirkan manusia-manusia pembawa perubahan menuju masyarakat yang keadilan dan berkeadaban. ${ }^{2}$

Masih dari perspektif filsafat, dalam artikelnya Fadli mendeskripsikan tentang konsep pendidikan Paulo Freire yang beraliran filsafat humanisme. ${ }^{3}$ Kekayaan prespektif terhadap pemikiran Freire, mengantar Alparizi, menfokuskan tulisan pada pendidikan emansipatoris menurut Paulo Freire. ${ }^{4}$ Empat artikel ini menekankan pada relevansi pemikiran Freire di luar gereja.

Berikut ada tulisan yang menghubungkan pemikiran Freire dengan gereja. Hutabarat menulis kajian tentang pedagogi hati yang dikemukakan secara khusus oleh Paulo Freire. Pedagogi hati direlevansikan sebagai salah satu model Pendidikan Agama kristen (PAK) bagi warga gereja di Indonesia. Pedagogi hati adalah sebuah model

\footnotetext{
${ }^{1}$ Rijal Abdillah, “Analisis Teori Dehumanisasi Pendidikan Paulo Freire," Jaqfi: Jurnal Aqidah dan Filsafat Islam, Vol.2, No. 1 (2017): 1

2 Rohinah Rohinah, "Re-Konsientisasi dalam Dunia Pendidikan (Membangun Kesadaran Kritis melalui Pemikiran Paulo Freire)," Tarbiyah: Jurnal Ilmiah Kependidikan, Vol. 8, No.1 (2019), 1.

3 Rizky Very Fadli, "Tinjauan Filsafat Humanisme: Studi Pemikiran Paulo Freire Dalam Pendidikan," Reforma: Jurnal Pendidikan dan Pembelajaran, Vol. 9, No.2 (2020): 96.

4 Patur Alparizi dan Ach. Nurholis Majid, "Pendidikan Emansipatoris Dalam Perspektif Paulo Freire Dan Muhammad Abduh,” Jurnal Inovasi Penelitian, Vol. 1, No.9 (February 2021),1885
} 
pendidikan politik yang berpusat pada hati nurani Pengembangan pedagogi hati atau dalam istilah PAK pengembangan seutuhnya manusia khususnya ranah afektifnya sangat penting karena PAK berdasar pada Alkitab yang berisi tentang kesaksian dan pengenalan serta pertumbuhan iman warga Gereja pada Tuhan Yesus Kristus. ${ }^{5}$

Beberapa tulisan di atas menunjukkan kekayaan pemikiran Freire yang dapat dimanfaatkan dalam gereja dan di luar gereja dengan berbagai perspektif. Ada penekanan berulang tentang membangun pemikiran kritis dan humanisasi serta emasipatoris bahkan pedagogi hati. Sekalipun demikian, tulisan ini menambah kajian relevansi pemikiran Freire khusus dalam gereja, dengan mengusung konsep pemikiran Freire yang unik yakni: gereja yang profetik.

\section{Metode Penelitian}

Metode yang digunakan dalam tulisan ini ialah metode deskriptif. Penelitian deskriptif merupakan upaya mendeskripsikan atau menganalisis suatu gejala, peristiwa yang terjadi pada masalah. ${ }^{6}$ Upaya ini ditindaklanjuti dengan argumen-argumen terhadap gejala atau peristiwa pada masalah yang terkait. Metode deskriptif digunakan penulis dengan mulai focus pada menggambarkan pemikiran Paulo Freire mengenai pendidikan pembebasan oleh gereja dalam konsep gereja yang profetik. Kemudian pemikiran Freire tersebut, dielaborasi dan dikaji dengan perspektif pendidikan kristiani untuk menemukan konsep teologis dalam pemikiran Freire tersebut, yang kemudian dapat ditarik relevansinya bagi kehidupan bergereja di manapun pada masa kini.

\section{Hasil dan Pembahasan}

Paulo Freire adalah seorang tokoh pendidikan.7 Ia lahir pada tanggal 19 September 1921 di Recife, Brasilia. Ia berasal dari keluarga menengah, namun sejak masa kecilnya ia hidup dalam situasi miskin karena keluarganya tertimpa kemunduran finansial, yang diakibatkan oleh krisis ekonomi yang melanda Amerika Serikat sekitar tahun 1929, yang juga dampaknya menular ke Brasil. ${ }^{8}$ Keadaan miskin tidak mematahkan semangatnya. Ia tetap berjuang menyelesaikan pendidikan, dan memenuhi syarat untuk mengikuti sekolah lanjutan pada usianya yang ke 15 tahun. ${ }^{9}$ Kemudian, ia melanjutkan pendidikan

5 Oditha R. Hutabarat, "Pedagogi Hati: Model Pak Sebagai Pendidikan Politik Bagi Warga Gereja Di Indonesia," Voice of Wesley: Jurnal Ilmiah Musik dan Agama, Vol. 2, No.1 (2018)

${ }^{6}$ Admin. "Definisi Metode Deskriptif." idtesis.com. https://idtesis.com/metode-deskriptif/.(diakses 20 Mei 2021)

7 Budi M. Rachman, Islam Pluralis: Wacana Kesetaraan Kaum Beriman (Jakarta: PARAMADINA, 2001), 368.

8 Paulo Freire, Pendidikan Sebagai Praktek Pembebasan, penerjemah: Alois A. Nugroh (Jakarta: PT Gramedia,1984), 157.

9 Paulo Freire, Pendidikan Kaum Tertindas, terj: Tim Redaksi LP3ES, cet. 7 (Jakarta: LP3ES, 2011), xi. 
ke jenjang yang lebih tinggi dengan masuk ke Universitas Recife, Fakultas Hukum, sambil terus mempelajari filsafat dan psikologi bahasa. ${ }^{10}$

Tahun 1944 Freire menikahi Elza Maia Costa Oliviera dari Recife, yang adalah seorang guru sekolah dasar. Pernikahan mereka dikaruniai dua orang putra dan tiga orang putri. Setelah masa pernikahannya, minatnya terhadap pendidikan mulai bertumbuh. Ia membaca buku-buku filsafat dan sosiologi pendidikan, serta teori-teori pendidikannya mulai muncul. ${ }^{11}$ Pada tahun 1959, Freire meraih gelar doktor dalam bidang sejarah dan filsafat pendidikan. Dalam disertasinya di Universitas Recife, ia mengemukakan pemahamannya mengenai filsafat pendidikan. Kemudian ia terus berkarya sebagai guru besar sejarah. ${ }^{12}$

Latar belakang kehidupan Freire dan sikapnya yang selalu berpihak pada sesamanya yang mengalami ketidakadilan, membuatnya memerangi ketidakadilan dan mengupayakan pembebasan lewat bidang yang digelutinya yaitu pendidikan. Freire berupaya menumbuhkan kesadaran yang kritis dalam diri masyarakat. Untuk itu ia menentang model pendidikan gaya bank di Brasil yang hanya melahirkan penindas berikutnya, karena bagi dirinya pendidikan gaya bank bukan pendidikan yang membebaskan.

Dalam karya-karya Freire, penuh syarat menuju perubahan. Penuh kritikan pada semua aspek kehidupan yang melanggengkan penindasan dan ketidakadilan. Sebagai pemikir progresif, filsuf, tokoh pendidikan dan sekaligus pendidik Kristen menjadikannya pribadi yang tidak segan-segan menyuarakan keberpihakannya terhadap kaum tertindas. Bahkan tidak segan-segan bersuara memberi kritik terhadap gereja. Pada masanya ia menilai gereja tidak relevan dengan konteks keterpurukan saat itu. Jabatan dalam penasehat Dewan Gereja Dunia bagian pendidikan membuat dirinya melihat, memahami dan menilai model gereja saat itu dan memberi kritikan yang relevan. Kritiknya melahirkan usul dalam bentuk konsep gereja yang profetik. Pemikirannya mengenai gereja yang profetik lahir dari hubungannya yang intim dengan Kristus. Bagaimana dirinya memahami Kristus yang dikenalnya dalam kekristenan diperhadapkan dengan realitas kehidupannya yang dialami dirinya dalam dunia.

\section{Latar belakang pemikiran Paulo Freire mengenai Gereja yang Profetik}

Freire berusaha menjelaskan semua unsur yang melanggengkan penindasan termasuk gereja. ${ }^{13}$ Memang tidak sebanyak pendidikan di sekolah serta kurikulum pendidikan

10 Denis Colins, Paulo Freire: Kehidupan, Karya, dan pemikirannya, Penerjemah: Hendri Heyneardhi dan Anastasia P, cet. 3 (Yogyakarta: Pustaka Pelajar, 2002), 6.

11 Ibid, 8

12 Muh. H. Dhakiri, Paulo Freire, Islam, dan pembebasan (Jakarta: Djambatan dan penerbit Pena, 2002), 18.

13 Paulo Freire, Politik Pendidikan, Kekuasaan dan Pembebasan, terj: Agung Prihantoro dan Fuad A. Fudiyartanto, cet.6 (Jakarta: Pustaka Pelajar, 2007), 218-130 
formal lainnya, tetapi semangatnya tidak luntur untuk memberi diri berbicara mengenai gereja, pendidikan dan upaya pembebasan. Ia mampu melontarkan kritik dan sekaligus memberi solusi bagi gereja pada masanya.

Pengalaman Freire, atau dialog yang dialaminya, atau lebih tepatnya perjumpaan dirinya sebagai pendidik Kristen dengan konteks di mana ia hidup, telah melahirkan konsep gereja yang profetik. Gereja yang profetik merupakan usulan dalam kritikannya terhadap gereja masa itu. Di mana konteks Brasil dan juga wilayah Amerika Latin saat itulah yang mendorong lahirnya konsep gereja yang Profetik. Realitas kemiskinan dan keterpurukan, kesenjangan social, pembatasan hak, eksploitasi manusia, merupakan beberapa hal yang melahirkan konsep gereja yang profetik. Secara umum semuanya itu merupakan bagian dari tema besar yang digumuli Freire yaitu penindasan yang berlangsung, sebagai akibat dari pengaruh feodalisme yang berkembang kuat saat itu. ${ }^{14}$

Realitas yang pincang dan tema besar yang digumuli pada dasarnya menghantarkan Freire pada teori konsientisasi yang dibicarakannya dalam bidang yang digelutinya yaitu pendidikan. Kemudian dikembangkan ke ranah gereja dan dibahas lebih lanjut dalam apa yang dinamakan proses konsientisasi oleh gereja. Secara singkat konsientisasi menurut Freire adalah proses menyadari realitas dan berdaya juang merubah realitas, dalam dialog yang terus menerus antara aksi dan refleksi.

Proses konsientisasi oleh gereja, dalam bahasa Freire, adalah upaya gereja untuk keluar dari realitas yang pincang dengan cara yang bertanggungjawab. Hal tersebut nampak dalam konsep gereja yang profetik, yang sekaligus adalah salah satu alternatif keluar dari realitas pincang. Dalam semangatnya yang membara, dan ketika filsafat pendidikannya mulai menyentuh lingkup gereja, Freire sadar betul bahwa tidaklah mungkin berbicara pendidikan, pembebasan dan gereja tanpa melihat sejarah gereja. ${ }^{15}$ Dengan demikian, untuk memahami pendidikan dalam gereja yang mengarah pada pembebasan maka harus mengetahui dengan benar realitas di mana gereja itu berada.

Realitas yang terjadi pada masa itu adalah realitas yang pincang, karena manusia hidup dalam situasi penindasan. ${ }^{16}$ Lebih jelasnya Freire mengatakan bahwa sebagian masyarakat hidup dalam keadaan yang serba berkelebihan dan sebagian lagi hidup dalam istilah kaum rombeng di muka bumi, yang serba berkekurangan. Situasi penindasan yang Freire maksudkan tidak sebatas pada dua kelas yang berbeda, tetapi lebih menekankan pada keadaan kaum tertindas sebagai yang mayoritas. Di tengah realitas yang demikian, Freire menempatkan dirinya untuk bersuara dari kelompok yang di mana dirinya juga berasal dari kelompok tersebut, yaitu kelompok kaum rombeng atau kaum tertindas. Sangat tegas dalam karya-karyanya memperlihatkan keberpihakannya pada kaum tertindas. Perjuangannya didasari oleh perenungan akan imannya kepada Kristus, bahwa ditengah realitas yang demikian gereja sudah

\footnotetext{
${ }^{14}$ Hanif Dzakiri, Islam dan Pembebasan (Jakarta: Djambatan dan PENA, 2000), 20.

15 Paulo Freire, Politik Pendidikan, 201.

16 ibid, vii.
} 
seharusnya memaknai cinta kasih Kristiani dengan menaruh perhatian pada kasuskasus eksploitasi manusia. ${ }^{17}$ Karena bagi dirinya, eksploitasi tersebut menjauhkan manusia dari eksistensi kemanusiaannya.

Bagi Freire kaum tertindas selalu ada di setiap belahan dunia ini dan hidup dalam penindasan. Lebih jauh lagi, kehidupan dalam penindasan selalu disertai minimnya kesadaran dari setiap manusia untuk keluar dari situasi tersebut dengan alasan yang beragam. Apapun nama dan alasannya, penindasan adalah sesuatu yang tidak manusiawi. Penindasan selalu menyangkal harkat kemanusiaan atau dengan kata lain dehumanisasi, seperti yang dikatakan Freire. ${ }^{18}$ Dehumanisasi memiliki sifat ganda dalam pengertian terjadi atas diri mayoritas kaum tertindas dan juga atas diri minoritas kaum penindas. ${ }^{19}$ Hal inilah yang perlu untuk diperhatikan bersama bahwa, baik kaum tertindas dan penindas sama-sama menyalahi kodrat manusia sejati. Kodrat manusia sejati adalah sebagai subyek yang kritis, yang tidak hanya mampu beradaptasi, tetapi berintegrasi untuk menjadi manusia seutuhnya. ${ }^{20}$

Kaum tertindas menjadi tidak manusiawi karena dibatasi hak-haknya dengan berbagai bentuk, dan terbenam dalam kebudayaan bisu. Sedangkan kaum penindas adalah setiap individu maupun kelompok yang menjadi tidak manusiawi karena mendustai hakekat hati nurani dengan memaksakan penindasan bagi sesama, ${ }^{21}$ serta tidak memberi diri untuk berjuang bersama keluar dari keadaan tersebut. Lebih tepatnya subjek (penindas dan kaum tertindas) dalam realitas penindasan tidak memiliki kesadaran akan apa yang dialami dan apa yang terjadi dalam kehidupan mereka. Dampaknya adalah tidak ada keberanian keluar dari zona mereka untuk menuju ke arah yang lebih baik bersama manusia yang lain dengan kelas yang berbeda.

Latar belakang yang mendorong munculnya konsep gereja yang profetik adalah realitas sejarah yang pincang. Realitas yang penuh dengan kontradiksi dan warna-warni dehumanisasi, penindasan yang ditandai dengan pembatasan hak, kemiskinan, eksploitasi manusia, kebudayaan bisu, kesenjangan social, perbedaan kelas yang sangat kontras, dimana yang menjadi mayoritasnya adalah kaum tertindas, dengan kata lain terpeliharanya kesengsaraan kolektif. Selain itu, latar belakang munculnya konsep gereja yang profetik juga disertai refleksi yang mendalam Freire akan imannya kepada Kristus.

Hal penting lainnya yang menjadi perhatian adalah pendidikan. Pada kenyataannya, Freire menilai bahwa pendidikan di tengah realitas yang demikian tidak menumbuhkan kesadaran kritis, melainkan pendidikan yang melanggengkan situasi

\footnotetext{
17 Ibid, 13.

18 Ibid, vii.

19 Ibid

20 Ibid, ix.

21 Ibid, vii.
} 
yang tidak seharsunya dengan berbagai bentuk dan namanya. Terkhususnya Freire mengidentifikasi model pendidikan yang berkembang saat itu adalah model pendidikan "gaya bank". Di tengah realitas yang demikian peran setiap unsur yang menjadi muara pendidikan berlangsung dipertanyakan, termasuk didalamnya gereja. Freire menilai bahwa gereja pada masa itu mengambil sikap yang kurang tepat. Dirinya menilai keterlibatan gereja dalam realitas pincang tersebut sebatas sikap diam dan netral dan tanpa kesadaran bahwa sedang terlibat melanggengkan realitas yang pincang. Inilah yang membakar semangatnya untuk melihat lebih dalam peran gereja dalam menyatakan tanda-tanda kerajaan Allah ditengah realitas dunia yang pincang.

\section{Gereja yang Profetik Sebagai Alternatif}

Berdasarkan konteks yang menjadi latar belakang munculnya konsep gereja yang profetik, gereja, di mata Freire sudah seharusnya berjuang menyatakan tanda-tanda kerajaan Allah (kehendak Allah yang terjadi di dunia), yaitu melalui segala upaya yang bertanggungjawab, dalam proses menuju pembebasan. Gereja tidak boleh sebatas beradaptasi atau menyesuaikan diri dengan konteks yang demikian, tetapi perlu menyadari keterpanggilannya untuk kritis dan berjuang dengan semangat kebersamaan, menuju realitas yang lebih baik dari sebelumnya.

Betapa pentingnya kesadaran untuk tidak sebatas beradaptasi, karena beradaptasi dalam makna yang umum adalah menyesuaikan diri dengan keadaan lingkungan sekitar, tanpa merubah keadaan tersebut. ${ }^{22}$ Dengan demikian, gereja harus benar-benar menyadari hal tersebut untuk tidak sebatas beradaptasi, tetapi lebih dari pada itu gereja harus mampu bergerak menuju realitas yang lebih baik dari sebelumnya. Hal ini sejalan dan diperkuat dengan apa yang disampaikan Leonardo Boff yaitu, ketika dijumpai bahwa suatu realitas sedang tidak baik-baik saja tetapi membiarkannya terus terjadi, maka gereja sedang terlibat dalam sesuatu yang salah dan jahat. ${ }^{23}$ Dengan catatan bahwa melihat realitas dengan menggunakan kacamata Injil.

Terlepas dari semua keharusan yang dibicarakan Freire, realitas yang terjadi jauh dari apa yang diharapkan. Gereja tetap eksis tetapi masih jauh dari apa yang diharapkan. Dalam sejarahnya, benar adanya bahwa gereja berjuang untuk tetap eksis di tengah konteks dimana dirinya berada. Namun, upaya untuk tetap eksis di tengah realitas yang pincang tersebut, banyak gereja yang mulai kehilangan arah dan turut melanggengkan realitas yang pincang tersebut. Lebih parahnya lagi gereja tidak menyadari bahwa sedang terlibat dalam sesuatu yang salah, yaitu terlibat melanggengkan realitas yang pincang.

Perjuangan gereja untuk tetap eksis, untuk terus memaknai keberadaannya di tengah realitas yang pincang, gereja perlu menemukan jalan keluar yang tepat agar tetap

\footnotetext{
22 Pusat Pembinaan dan Pengembangan Bahasa, Kamus Besar Bahasa Indonesia, Jakarta: Balai Pustaka, cet-10, 1999, 6.

${ }^{23}$ Leonardo Boff, Kekristenan: Sebuah Iktisar (Maumere: Ledalero, 2014), 91.
} 
eksis dengan bertanggungjawab. Gereja tetap eksis dengan terus memperjuangkan pembebasan dari system sosial yang tidak adil dan berdampak pada dehumanisasi. Sebagai usulan, Freire menekankan bahwa kesadaran adalah pintu masuk menuju pembebasan. Pendidikan adalah sarana menuju perubahan yang diimpikan lewat pembentukan kesadaran atau dengan kata lain pendidikan penyadaran. Catatannya adalah model pendidikan yang membebaskan bukan pendidikan yang tidak memiliki agenda untuk keluar dari situasi sebelumnya. Jadi, perlu untuk melihat kembali peranan gereja menuju pembebasan dalam sejarahnya.

Penting untuk diketahui bahwa untuk mempermudah menganalisis peran gereja yang lebih mendalam, maka perlu melihat gereja dan ajarannya dalam konteksnya. Berdasarkan analisis yang dilakukan, Freire menemukan model-model gereja dan ajarannya dalam sejarah keberadaannya di dunia dan dikaitkan dengan tahap kesadaran manusia dalam upaya menunjang teori konsientisasi, yaitu:

\section{Gereja Tradisional}

Model gereja ini berjuang untuk tetap eksis, tetapi sangat kolonialis. ${ }^{24}$ Bahkan Freire mengatakan dapat juga diebut gereja misionaris. Karena, yang menjadi penekanannya ialah menarik banyak jiwa lewat ajaran perbedaan yang kontras antara keduniawian dengan yang transendental. Hal-hal yang menyangkut urusan duniawi sangat dipisahkan dari yang transendental. Dunia adalah tempat di mana manusia harus membayar semua dosa-dosanya. Lebih tepatnya yaitu semakin menderita maka semakin bersihlah manusia, hingga pada akhirnya akan sampai pada tempat peristirahatan abadi yaitu surga.

Seorang ahli sosiologis asal Swis, Christian Laive, mengatakan bahwa model gereja ini memahami bahwa dunia hanyalah sebagai tempat persinggahan semata. 25 Karena hanya sebagai tempat persinggahan semata maka pemikiran ke arah transformasi sangatlah jauh dari garis tradisional ini. Pemahaman seperti ini sangat disukai oleh penganut paham fatalistic, tetapi sangat tidak menguntungkan kaum tertindas. Freire mengatakan bahwa dengan pemahaman yang demikaian, maka kaum tertindas seolah-olah tidak menemukan obat penyembuh atas keletihan mereka. ${ }^{26}$ Yang ada hanyalah sebatas ajaran religius yang menjanjikan kehidupan abadi menanti diakhir semua penderitaan sebagai proses pembersihan ini.

Dampak dari pemahaman seperti ini adalah gereja hanya dipahami sebagai tempat persembunyian sementara dari struktur sosial yang menindas. Terlebih lagi, karena yang menjadi mayoritas adalah kaum tertindas, maka banyak jiwa mencari gereja untuk berlindung sementara. Inilah yang Freire katakan bahwa garis tradisional

24 Ibid, 220.

25 Ibid.

26 Ibid, 221. 
sangat identik dengan gereja misionaris. Freire mengatakan bahwa perlu untuk disadari dalam model seperti ini, masyarakat terjebak dalam kehidupan yang membisu terhadap setiap bentuk penindasan yang dialami. ${ }^{27}$ Dengan kata lain, kebudayaan bisu dipelihara terus-menerus dalam sejarah kehidupan di dunia yang katanya tempat persinggahan ini, dan gereja turut melanggengkannya. Karena, gereja tidak menyentuh persoalan mendasar yang dihadapi kaum tertindas, tetapi malah sebatas mengarahkan kaum tertindas untuk membenci dunia yang jahat ini dan meminimalisir keterlibatan membentuk sejarah dalam dunia dengan arus transformatif. Pemaknaan ini sama dengan Karl Marx dalam konsep agam sebagai candu, oleh karena pemikiran Freire juga dipengaruhi oleh Karl Marx. Sekalipun begitu, Freire tetap mengkritisi Karl Marx dengan menolak gagasan yang diusungkan Karl Marx yang bersifat antagonis, memandang kelas elit-borjuis sebagai kelas yang harus dihancurkan supaya tercipta masyarakat tanpa kelas. Selain itu, dalam kaitanya dengan Karl Marx, Freire juga dipengaruhi oleh pemikiran Gustavo Gutierrez yang memakai pemikiran Marx untuk mencetuskan teologi pembebasannya. Namun, Freire juga menolak gagasan teologi pembebasan yang melanggengkan segala cara. Freire menawarkan aksi dialog dalam rangka pendidikan untuk pembebasan bukan aksi penghancuran.

Alasan lebih mendalam adalah dominannya warna tingkat kesadaran Magis atau kesadaran semi intransitive. ${ }^{28}$ Di mana warga gereja atau masyarakat sangat tertutup, tidak mampu menyadari realitas atau tidak dapat mengobyektifikasi fakta dan kehidupan sehari-hari yang penuh dengan problematik, bahkan tidak dapat memahami keterkaitan antara kemiskinan dengan struktur sosial, ekonomi, politik, dan budaya yang mengindisikan kemiskinan yang dialami. Sebagaimana Freire, Smith juga mengatakan bahwa masyarakat dalam kesadaran magis ini adalah masyarakat yang tidak mampu melihat antara kemiskinan mereka dengan sistem politik dan kebudayaan. ${ }^{29}$

Dapat digarisbawahi bahwa dengan tingkat kesadaran yang demikian, gereja tradisional memainkan peran pendidikannya seputar pada cara pandang terhadap dunia, takdir dan agama, dalam tingkat kesadaran magis yang dominan. Akhirnya gambaran pendidikan yang biasanya diterapkan yaitu berharap dapat mencapai transendensi tanpa melewati dunia, menginginkan meta-sejarah tanpa melalui sejarah, yang artinya tidak mampu melihat kemungkinan di masa depan yang proyeknya dimulai dari saat ini atau minim pemaknaan akan pengharapan. Model seperti ini juga menginginkan keselamatan tanpa melakukan pembebasan. Karena, yang dipahami adalah rasa sakit dan penderitaan diterima sabagai nasib yang sudah seharusnya dijalani dalam memerangi dosa.

27 Ibid.

28 Ibid, 135-137.

${ }^{29}$ William A. Smith, Konsientisasi (Yogyakarta: Kanisius, 2004), xvii 
Freire mengkritisi model ini karena menurutnya gereja kurang memaknai keberpihakan pada kaum tertindas. Model ini sebatas menerima nasib dan menolak dunia ini, tanpa berani melihat bahwa struktur yang menindas tersebutlah yang membuat dunia ini terkesan jahat. Dengan demikian, pembebasan sulit ditemukan dalam model seperti ini.

\section{Modernisasi Gereja}

Dalam perkembangannya, sejarah menunjukkan bahwa gereja telah mengalami perkembangan. Gereja, walaupun tidak semuanya, sudah mulai meninggalkan perspektif tradisional dan memulai dengan sudut pandang yang baru. Perspektif yang baru muncul seiring perkembangan dunia menuju modernisasi. Freire mengatakan bahwa elemenelemen modernisasi mulai menggantikan struktur sosial yang bersifat tradisional. ${ }^{30}$

Dalam perspektif yang baru ini, gereja berjuang untuk tetap eksis di tengah masa transisi yang sedang berlangsung. Yang menarik pada masa ini adalah kaum borjuis bekerjasama dengan kaum proletar yang sedang bertumbuh di dunia industrialisasi. Namun, kerjasama yang terjadi tidak terlepas dari kepentingan kelompok penguasa.

Gereja eksis di tengah perspektif pasar yang mencari cara menemukan upayaupaya baru untuk mereformasi struktur social yang bersifat tradisional tanpa mengganggu kepentingan penguasa atau pemilik modal atau kaum borjuis. Kaum penguasa menekankan bahwa proses reformasi ini tidak boleh merusak posisi mereka sebagai yang menentukan kehidupan kaum lemah. Kaum lemah harus tetap bergantung pada penguasa.

Akhirnya proses reformasi yang dibicarakan tersebut sampai pada kesimpulan bahwa proses itu dinamakan "pembangunan". Kritik Freire yaitu, pembangunan yang dimaksudkan hanya sebatas upaya gereja menyesuaikan diri dengan perubahan yaitu menggantikan alat-alat manual ke alat modern yang berteknologi tinggi (fisik), tanpa mau merubah sistem penindasan. Bagi Freire pembangunan seperti itu tidak dapat dikatakan pembangunan dalam arti yang sebenarnya, dan gereja modern tidak benarbenar menyentuh makna pembangunan yang sebenarnya. Oleh karena, pembangunan yang sejati adalah proses pembebasan bagi masyarakat yang menderita. ${ }^{31}$

Gereja modern sibuk dengan ajaran modernisasi tanpa menerjemahkan konsep pembebasan yang seharusnya melibatkan kaum tertindas dalam proses membentuk sejarah. Dampaknya ialah modernisasi menuju pembebasan tidak benar-benar menyentuh hal mendasar antara masyarakat yang dikuasai dan yang menguasai. Pada sisi yang lain, bagi Freire, gereja modern tidak dapat disalahkan karena berusaha eksis dengan sarana kerja yang ada atau teknologi yang canggih, tetapi salah karena pilihan

\footnotetext{
30 Paulo Freire, Politik Pendidikan, 223.

31 Ibid, 225.
} 
politiknya yang jelas-jelas mengkondisikan modernisasi tersebut. Artinya gereja keliru jika mengikuti arus modernisasi dengan menjadi gereja modern tanpa kritis terhadap konteks dan tanpa memiliki komitmen untuk berpihak pada kaum tertindas, tetapi sebaliknya berpihak pada elit penguasa.

Ketika gereja tradisional mengasingkan kaum tertindas dengan mengajari mereka bahwa dunia ini jahat, gereja modern mengasingkan kaum tertindas dengan mengajari mereka mengenai humanisme kapitalis ketimbang menumbuhkan kesadaran akan realitas penindasan yang kejam. Humanisme yang dibicarakan jauh dari makna yang sebenarnya, karena gereja modern tidak memberi diri menuju pembebasan. Gereja modern terlibat melakukan berbagai cara untuk mempertahankan status quo. Freire menegaskan bahwa tidak ada humanisme tanpa pembebasan, dan tidak ada pembebasan tanpa transformasi masyarakat kelas, karena dalam masyarakat yang demikian (kelas yang menindas) tidaklah mungkin ada humanism sejati. ${ }^{22}$ Untuk itu, gereja modern dikatakan mati karena hanya sebatas memiliki kesadaran naif dan menolak perubahan yang lebih mendasar.

Kesadaran naif dalam garis modernisasi gereja ini merupakan tahap kesadaran yang lebih tinggi dari kesadaran magis. Kesadaran naif mendominasi dalam garis modernisasi gereja. Tahap ini menyadari bahwa ada kelas yang berbeda, terbelakang, dan adanya penindasan, hanya saja kurang mampu memetakkan secara sistematis persoalan-persoalan yang mendukung realitas tersebut, apalagi memberi tawaran solusi terhadap realitas problem sosial yang dialami. Selain itu, kesadaran tahap ini memahami bahwa struktur adalah "pemberian" dan tidak perlu dipertanyakan lagi.

Freire mengkritisi garis modernisasi ini karena dengan kesadaran yang demikian berdampak pada kecenderungan gereja modern membicarakan kemiskinan dan keterbelakangan tetapi menolak berbicara mengenai penindasan. Lebih lagi, gereja takut berbicara mengenai pertentangan antara kelas yang dikuasai dan kelas yang menguasai, karena dapat mengancam posisi mereka.

Dengan demikian dapat disimpulkan bahwa, gereja modern memiliki perspektif yang lebih baru dari gereja tradisional, tetapi masih sama dalam hal tidak memberi diri untuk berkomitmen pada ketertindasan yang dialami kaum lemah. Gereja modern memiliki konsep pendidikan dan tujunnya didasari pada sikap yang dikatakan netral, seolah-olah menghindari kontradiksi yang terjadi, tetapi tanpa disadari berpihak pada elit penguasa. Pendidikan yang terjadi ditujukan untuk menyesuaikan diri dengan keadaan atau sruktur yang sudah ada, berekspresi pada batasan-batasan kelas yang sudah ditentukan.

\section{Gereja yang profetik}

32 Ibid, 229. 
Berdasarkan kekurangan yang dibicarakan dari model gereja tradisional dan modernisasi gereja, Freire menawarkan konsep gereja yang profetik sebagai alternatif. Tawaran yang dimaksudkan adalah ajakan merefleksikan keberadaan gereja di tengah dunia dengan cara yang berbeda sesuai dengan apa yang dikatakannya sebagai gereja yang profetik. Gereja yang profetik memberi warna yang berbeda ketimbang gereja tradisional dan gereja modern. Gereja yang profetik selalu penuh dengan harapan dan menolak perubahan yang hanya sekedar meredakan, tetapi lebih pada perjuangan bersama menuju penyembuhan dan pembebasan.

Gereja yang profetik selalu berpikir kritis dan menolak pemikiran yang statis. Gereja yang profetik merefleksikan iman kepada Allah tanpa memisahkan diri dari dunia. Gereja yang profetik eksis dalam dunia modern tetapi tidak terjebak pada batas modernisasi semata.

Kata profetik dapat dimengerti lebih dalam ketika dianggap sebagai ungkapan berdasarkan analisis dan refleksi kondisi dunia ketiga yang dramatis, yang dipenuhi dengan kontradiksi dan konflik dalam masyarakat. Sambil mengingat pembahasan sebelumnya bahwa dunia ketiga yang dimaksudkan Freire adalah dunia yang bisu, tertindas, dieksploitasi, dan menjadi objek kekerasan oleh penguasa. ${ }^{33}$

Jadi, gereja yang profetik adalah gereja yang memahami keberadaannya ditengah realitas yang penuh dengan kontradiksi dan konflik. Di tengah kontradiksi yang terjadi, gereja profetik menolak sikap netral dan sangat kontras menunjukan keberpihakannya. Dalam upaya memahami keberpihakan gereja yang profetik, dapat dimulai dengan melihat realitas kontradiksi antara kelompok kelas yang berbeda. Kemudian, baik antara kaum penindas dan kaum tertindas, gereja yang profetik berpihak pada kaum tertindas tanpa mengabaikan kelas yang lain. Artinya keberpihakan gereja yang profetik jatuh pada kaum tertindas dan sekaligus penindas dalam perjuangan bersama memerangi realitas penindasan. Keberpihakan gereja yang profetik adalah keberpihakan berdasarkan Injil.

Keberpihakan gereja yang profetik merupakan bentuk tanggungjawab dalam tugas yang diemban dalam keterpanggilannya. Tugas tersebut tidak terlepas dari resiko dan penolakan. Sebagaimana Yesus datang memporak-poranda hal-hal yang jauh dari tanda-tanda Kerajaan Allah, Ia pun ditolak bahkan dibenci dunia. Artinya, gereja yang profetik harus siap menerima setiap resiko yang muncul sebagai akibat dari keberpihakan.

Perjuangan yang nampak dalam gereja yang profetik didasari oleh kesadaran kritis. Kesadaran kritis atau Critical Consciousness, merupakan tingkat kesadaran yang ideal ketimbang tingkat kesadaran yang sebelumnya. Tahap ini dapat memetakan masalah, mengidentifikasi dan menentukan faktor-faktor yang mempengaruhi. Tidak

33 Paulo Freire, Politik Pendidikan, 235. 
sampai di situ saja, namun dapat juga memberikan solusi terhadap persoalan yang dihadapi. Tahap atau tingkat kesadaran kritis ini sudah mampu untuk menganalisis kritis terhadap struktur, sistem sosial, politik, ekonomi, dan budaya serta akibatnya terhadap keadaan masyarakat. ${ }^{34}$ Dalam tahap ini, maka gereja mampu menganalisis faktor-faktor yang mempengaruhi realitas pincang dalam sistem dan sturktur yang ada, serta berjuang mentransformasikan.

Kesadaran kritis yang diupayakan untuk dominan dalam gereja yang profetik bukanlah akhir dari perjuangan, tetapi terus berproses menuju tahap kesadaran yang penuh. Kesadaran penuh atau Transformation Consciousness adalah tingkat kesadaran yang diharapkan dan menjadi cita-cita bersama dalam semangat profetik. Kesadaran penuh atau dalam bahasa Freire "kesadarannya kesadaran (the consice of the consciousness) diharapkan dapat dimiliki oleh setiap individu agar penindasan dan segala dampaknya dapat diatasi. Freire mengutip pengertian filosofis ini dari Karl Jaspers, dan dengan mengutip pokok-pokok pemikiran filsuf politik eksistensialis lainnya, Jean-Paul Sartree, Freire tiba pada kesimpulan bahwa inti dari kesadaran manusia adalah intensionalitas pengalaman akan realitas (keterlibatan penuh dan sadar dalam suatu proses).

Kaitan menumbuhkan kesadaran kritis menuju kesadaran penuh nampak dalam proses konsientisasi yang dibicarakan Freire. Proses tersebut menjadi ciri khas gereja yang profetik, di mana semua anggota berpartisipasi membentuk kesadaran kritis individu kemudian menjadi praksis bersama atau komunal. Konsientisasi tidak hanya berdampak pada kaum tertindas yang memiliki kesadaran kritis tetapi juga kaum penindas. Kemudian kesadaran kritis individu kaum tertindas dan penindas menjadi kesadaran kritis bersama menuju kesadaran penuh yang mewujud dalam refleksi dan aksi yang terus menerus oleh mereka yang adalah kelompok progresif. ${ }^{35}$ Artinya, kesadaran kritis maupun kesadaran penuh bukanlah akhir dari tujuan gereja profetik, tetapi terus menerus diupayakan menjadi aksi dan refleksi.

Semangat gereja yang profetik dengan tahap kesadaran kritis berjuang untuk menanamkan kesadaran pada setiap pribadi bahwa realitas yang terjadi bukanlah sebatas fakta yang statis melainkan sebuah proses. Dengan demikian semangat merubah realitas yang pincang dapat bertumbuh, tidak seperti gereja tradisional yang hanya menerima nasib. Gereja yang profetik sadar betul akan proses menuju perubahan harus menyentuh akar persoalan agar tidak sebatas mengobati atau menahan konflik sementara. Karena menahan konflik memiliki sisi lain yaitu memperkuat kelas penguasa.

Upaya menyentuh persoalan mendasar dalam kontradiksi yang terjadi, dan untuk menciptakan sejarah yang baru, maka setiap individu terkhususnya kaum tertindas

\footnotetext{
34 Mansour Fakih, Roem Topatimasang, Toto Rahardjo, Peny. Pendidikan Popular: Membangun Kesadaran Kritis, (Yogyakarta: Pustaka Belajar, 2000), 30.

35 Paulo Freire, Politik Pendidikan, 234.
} 
harus terlibat dalam proses transformasi tersebut. Transformasi yang diupayakan tidak jatuh sama dengan transformasi yang dibicarakan dalam gereja yang modern. Dalam upaya transformasi, gereja yang profetik melihat pembangunan dalam refleksi teologi pembebasan. Di mana pembangunan yang diupayakan lebih kearah pembebasan dari penderitaan, tidak hanya sebatas berpacu dalam dunia yang semakin cepat, dengan menggunakan teknologi semata atau unsur-unsur modern lainnya, seperti terjebak dalam konsep pembangunan fisik semata, terjebak dalam sistem birokrasi, dan lain-lain. Untuk itu, dengan kesadaran kritis, penganutnya terkhususnya kaum tertindas dituntut harus mampu menganalisis realitas yang terjadi. Di sinilah salah satu ciri pembeda gereja yang profetik, ketimbang gereja tradisional maupun gereja modern. Gereja yang profetik menyadari realitas penindasan sekaligus menyadari bahwa pendidikanlah jalan keluar menuju pembebasan. Peran pendidikan yang dilakukan gereja yang profetik, merupakan agenda yang disengajai, atau dengan bahasa Freire disebut politik pendidikan, untuk memampukan kaum tertindas terlibat aktif yang dimulai dari menumbuhkan kesadaran akan realitas yang pincang. Oleh karena proses analisis ini membutuhkan ilmu pengetahuan yang baru, yang bernuansa transformative, yang jauh dari kehidupan mereka sebelumnya, maka sangat jelas dan perlu untuk disengajai.

Kesadaran bahwa pendidikan adalah sarana menuju pembebasan belum sepenuhnya menyelesaikan persoalan. Lebih jelasnya ialah pendidikan yang diharapkan dalam konteks penindasan adalah pendidikan pembebasan seperti yang telah dibicarakan sebelumnya. Maka, muatan pendidikan pembebasan merujuk pada tawaran-tawaran model pendidikan dari Freire, yaitu; pendidikan penyadaran, investigasi kenyataan, humanis dan pastinya dialog bersama dalam konsep pendidikan hadap masalah. Hal ini bukan sesuatu yang baru, tetapi memiliki muatan agenda pembebasan atau politik pembebasan yang menyentuh kontradiksi di tengah masyarakat, inilah yang menjadi ciri gereja yang profetik.

Ketika gereja tradisional memahami keterpanggilannya (dalam realitas penindasan) sebagai rumah yang memberikan perlindungan sementara bagi kaum tertindas, lalu gereja modern memodifikasi rumah tersebut dengan sentuhan unsurunsur modern, tanpa benar-benar menyentuh persoalan realitas penindasan, dan malah memasukkan unsur modern dalam gereja yang semakin melanggengkan realitas yang pincang, gereja yang profetik memiliki visi yang berbeda. Visi tersebut bukanlah pelarian menuju mimpi yang tidak tergapai. Gereja yang profetik memiliki visi bersama menuju kehidupan lain dengan warna yang lebih baik dari kehidupan sebelumnya yang penuh dengan warna penindasan. Visi tersebut dieksekusi dengan mengawali cara hidup yang berbeda, mulai dari sikap kritis di kehidupan sekarang, dan berjuang menjadi profetik lewat aksi-refleksi-aksi secara terus-menerus (proses). Di mana, 
"realitas" dipahami sebagai proses dari kontradiksi dan konflik yang terjadi, maka perlu disengajai menciptakan realitas yang lebih baik.

Bahasa lainnya, gereja profetik menghayati iman dalam pengharapan, dan berpengharapan tidaklah statis melainkan dinamis melalui sarana yang ditawarkan Freire yaitu pendidikan kesadaran menuju pembebasan. Dengan demikian muatan pendidikan dalam gereja yang profetik berbeda dengan model-model gereja sebelumnya. Pendidikan dalam gereja yang profetik menjadi upaya menjelaskan konteks di mana pendidik-peserta didik dan peserta didik-pendidik disatukan dalam aksi mereka.

Gereja yang profetik merupakan bagian yang tidak terpisahkan dengan teologi pembebasan yang berkembang juga di Amerika Latin. Hanya saja Freire memiliki pemahaman pembebasan yang sedikit berbeda dari teologi pembebasan yang dipelopori oleh Gutierrez. ${ }^{36}$ Penekanan Freire lebih pada mengimani Allah dalam realitas penindasan, menuntut gereja profetik memahami teologi pembebasan sebagai semangat profetik. Dalam semangat profetik tidak ada namanya keberpihakan yang disertai kebencian terhadap kelas yang lain. Semangat profetik mengarah pada kebebasan sebagai dampak dari konsientisasi oleh gereja yang harus tetap berada dalam terang Injil. Dengan demikian, jelaslah konsep gereja yang profetik tidak sebatas berjuang menumbuhkan kesadaran kritis dalam menganalisis realitas, tetapi juga mampu merefleksikan dan mewujudkan aksi dalam terang injil atau sebagaimana yang Yesus Kristus ajarkan. Selanjutnya, untuk dipahami lebih jauh, konsientisasi oleh gereja dilihat sebagai sarana menuju penyataan tanda-tanda kerajaan Allah, sebagaimana gereja memahami tugas dan panggilannya. Jadi, pada dasarnya kesadaran kritis bukan pada dirinya sendiri atau akhir dari perjuangan gereja yang profetik. Kristuslah petunjuk bagi sejarah, maka konsientisasi dibarengi refleksi-aksi-refleksi secara terus menerus dilakukan dalam upaya memahami sejarah di mana gereja itu hadir dan memahami upaya membentuk sejarah baru dalam pengharapan dalam Kristus.

Konsientisasi yang ditawarkan Freire sudah hadir sebagai alternatif dalam system pendidikan yang di dalamnya mengandung tujuan penyadaran dan pembebasan. Dengan kata kunci "sadar", manusia dapat melangkah lebih dari sekadar "bebas dari" penindasan, namun, melampaui dirinya menjadi "bebas untuk" berkarya tanpa ada tekanan yang menindas. Melalui pendidikan Freire mengharapkan mampu mendekonstruksi kenyataan sosial, ekonomi, dan politik serta merekonstruksi untuk menyelesaikan problem masyarakat. Konsientisasi oleh gereja mewajibkan gereja untuk menyadari dirinya, menyadari panggilannya, menyadari peran pendidikannya di tengah realitas dunia di mana dirinyaberada, yang penuh dengan kontradiksi dan godaan. Analisis Freire membatu gereja dalam mengambil sikap di tengah kontradiksi (menolak netral). Selain itu, membantu gereja juga untuk memahami dan mendalami peran

36 Paulo Freire, Politik Pendidikan, 213-217. 
sebagai agen dan wadah pendidikan, serta dapat menentukan agenda pendidikannya, tidak lagi hanya ikut-ikutan. Singkatnya bukan berarti gereja tidak melakukan apa-apa, tetapi pemikiran Freire tersebut memberi warna baru dan membantu gereja mengevaluasi kembali peranannya dalam dunia dan konteks masing-masing untuk lebih mengembangkan pelayanyannya menjadi lebih optimal. Serta memberi semangat kesetiaan dalam mengemban tugas sebagai yang terpanggil. Keterpanggilan gereja hidup dalam pengharapan akan janji Allah dapat direalisasikan saat ini, salah satunya dalam konsep gereja yang profetik. Di mana gereja dapat menentukan visi akan masa depan dalam Kristus, serta memerangi segala bentuk penyimpangan dari tanda-tanda kerajaan Allah. Pengharapan dalam Gereja yang profetik, akan masa depan dalam Kristus, membentuk manusia untuk berusaha menganalisis, berefleksi, dan mewujudkan aksi dengan tujuan mengantisipasi hal-hal yang tidak sesuai dengan masa depan dalam Kristus.

Hal lain yang perlu diperhatikan adalah sikap profetik dan proses membentuk sejarah, bukanlah milik pribadi dunia Amerika Latin seperti yang dibicarakan sejak awal mengenai konteksnya. Namun, sikap profetik, dan semangat gereja yang profetik menjadi milik semua manusia kristen di belahan dunia ini. Karena, umat Kristen sudah seharusnya bersifat profetik di mana dan kapan saja. ${ }^{37}$ Gereja yang profetik bukanlah milik pribadi dunia Amerika Latin tetapi dapat dimaknai dan diwujudkan oleh orang Kristen dimanapun berada. Semangatnya dan panggilannya tetap sama, hanya beberapa hal berada dalam hal konteks di mana persekutuan atau gereja itu berada.

\section{Hubungan gereja yang profetik dengan pendidikan kristiani}

Gagasan Freire mengenai konsientisasi, di mana pendidikan sebagai sarana pembebasan, dengan mengintegrasikan realitas sosial dalam pendidikan serta menumbuhkan kesadaran kritis, memberi sumbangsi besar bagi dunia pendidikan di manapun. Gagasan Freire digunakan untuk mengkritisi model pendidikan yang menindas, yang melanggengkan status quo, serta memberi warna baru dalam dunia pendidikan, terkhususnya pendidikan di negara-negara berkembang.

Jhon A. Coleman, mengatakan bahwa pendidikan, apalagi pendidikan kristiani sudah seharusnya berangkat dari bela rasa dan menolak sikap netral. ${ }^{38}$ Kemudian Freire menegaskan bahwa bahasa "netral" bukan hanya sebatas kata, namun berdampak pada kegiatan-kegiatan. Jadi, sikap netral dalam dunia pendidikan adalah bentuk kegiatan

37 Ibid, 235.

38 Jack L. Seymour, Memetakkan Pendidikan Kristen: Pendekatan-pendekatan Menuju Pembelajaran Jemaat (Jakarta: BPK Gunung Mulia 2016), 28. 
melanggengkan idiologi yang dominan, tanpa ada upaya melihat, mengevaluasi serta mengkritisi idiologi dominan yang berkembang. ${ }^{39}$

Jack L. Seymour juga menyetujui konsep pendidikan Freire. Secara khususnya ia juga berbicara mengenai pendidikan dalam gereja. Dengan mengutip Daniel S. Schipani, Seymour sampai pada kesimpulan bahwa gereja dalam memaknai panggilannya dalam terang pemerintahan Allah, sudah seharusnya memahami bahwa pendidikan dalam gereja atau pendidikan jemaat harus bernuansa menghadirkan kebebasan, keadilan dan pendamaian, dalam agenda politik kebangkitan manusia. ${ }^{40}$ Kebangkitan manusia yang dimaksudkan adalah proses menjadi lebih manusia dalam Anugerah dan Janji Allah, di mana proses tersebut menuntut partisipasi aktif jemaat.

Selain itu, sebagaimana Freire mengatakan bahwa Gereja yang profetik adalah sebuah alternatif, Seymour juga secara tidak langsung mendukung konsep tersebut. Dalam karyanya: Memetakkan Pendidikan Kristen; Pendekatan-pendekatan Menuju Pembelajaran Jemaat, Seymour dan Schipani menegaskan bahwa gereja dalam perjuangan memaknai panggilannya, terkhususnya bergumul lewat pendidikan, akan berhadapan dengan nilai-nilai dominan (Freire: idiologi yang dominan), dalam bentuk individualism, kompetisi yang menyingkirkan orang lain, konsumtif, militarisme, tidak terlepas juga dengan struktur yang menindas, dan sebagainya. Serta akan berhadapan juga dengan praktik dalam gereja yang patriarkat, moralisme, legalisme, serta kurangnya bela rasa (Freire: sikap netral). ${ }^{41}$ Dalam konteks yang demikian gereja benarbenar membutuhkan alternatif untuk tetap eksis dengan bertanggungjawab.

Lebih jauh lagi, konsep Freire mengenai pendidikan dalam gereja serta muatan konsientisasi menuju pembebasan dengan ciri dialog yang disertai refleksi-aksi secara terus menerus, diperjelas oleh pakar pendidikan, Thomas H. Groome. Sebagaimana Freire, Gromme dalam karyanya: Christian Religion Education, terkhususnya poin mengenai Share Christian Praxis (SCP), menegaskan bahwa pendidikan Kristen sudah seharusnya penuh akan makna dialog dan refleksi sebagai sesama subjek. Pendidikan Kristen dengan berbagi praksis bagi Groome dapat dipahami sebagai persekutuan umat percaya yang saling berbagi dalam dialog dan refleksi kritis atas tindakan masa kini dari sudut pandang cerita Kristen dan menentukan visi kearah iman Kristen yang hidup. ${ }^{42}$ SCP adalah bagian dari konsientisasi oleh gereja karena merupakan politik pendidikan gereja di mana SCP adalah sesuatu yang disengajai oleh gereja baik itu isi dan prosesnya, dalam menghadapi realitas. Dalam SCP, terdapat upaya menumbuhkan refleksi kritis untuk melihat masa kini sebagai bentuk dari masa lalu dan pembentuk masa depan. Kemudian mendialogkan dengan nilai kristiani dan menentukan visi misi masa depan

39 Paulo Freire \& A. Faundes, Belajar Bertanya, Pendidikan Yang Membebaskan (Jakarta: Gunung Mulia, 1995), 44.

${ }^{40}$ Jack L. Seymour Memetakkan Pendidikan Kristen, 26-27.

${ }^{41}$ Ibid, 27.

42 Thomas H. Groome, Christian Religious Education. Pendidikan Agama Kristen: Berbagi Cerita dan Visi Kita (Jakarta: BPK Gunung Mulia, 2011), 269. 
dengan bercermin pada Allah. ${ }^{43}$ Sangat jelas bahwa pendekatan pendidikan SCP ini sejalan dengan pemikiran Freire yang menawarkan model pendidikan hadap masalah. Model pendidikan ini bersifat membebaskan dan menumbuhkan kesadaran kritis sebagai protes terhadap model banking. Model pendidikan hadap masalah dapat diterapkan dalam gereja untuk mengkritisi keadaan sosial maupun dalam gereja. Metode belajar Freire ini lebih dikenal dengan metode penyadaran atau Konsientisasi menekankan pada kemampuan mengadakan refleksi kritis dan menerjemahkan hasil analisis yang mandiri di dalam aksi secara terus menerus. Hal utama yang perlu dikritisi dan dibebaskan adalah system bergereja yang bersifat dehumanisasi dan penyimpangan terhadap tanda-tanda Kerajaan Allah.

\section{Kesimpulan}

Pendidikan dalam konsep gereja profetik menurut Freire dapat dijadikan alternative oleh gereja dalam merespon konteks ketidakadilan dalam masyarakat. Hal ini penting sebab gereja dalam panggilannya ditengah-tengah dunia diharapkan dapat menghidupi nilai-nilai keadilan. Nilai keadilan yang dihidupi tersebut tentunya berdasarkan iman kepada Allah pembebas. Allah pembebas umat menjadi dasar bagi gereja dalam menyikapi ketidakdilan. Secara konkrit, pergerakan gereja dapat dimulai dengan mendidik umat untuk sadar konteks serta menumbuhkan kesadaran kritis umat terhadap konteks ketidakadilan yang terjadi. Selanjutnya, penulis merekomendasikan penelitian lanjutan tentang bagaimana pelaksanaan dan evaluasi pendidikan profetik dalam gereja.

\section{Referensi}

Abdillah, Rijal. “Analisis Teori Dehumanisasi Pendidikan Paulo Freire,” Jaqfi: Jurnal Aqidah dan Filsafat Islam, Vol.2, No. 1 (2017): 1-21.

Admin. "Definisi Metode Deskriptif." idtesis.com. https://idtesis.com/metodedeskriptif/.(diakses 20 Mei 2021)

Alparizi, Patur dan Ach. Nurholis Majid. "Pendidikan Emansipatoris Dalam Perspektif Paulo Freire Dan Muhammad Abduh," Jurnal Inovasi Penelitian, Vol. 1, No.9 (February 2021),1885-1896.

Boff, Leonardo, Kekristenan: Sebuah Iktisar, Maumere: Ledalero, 2014.

Colins, Denis, Paulo Freire: Kehidupan, Karya, dan pemikirannya, Terjemahan. Hendri Heyneardhi dan Anastasia P, cet. 3, Yogyakarta: Pustaka Pelajar, 2002.

Dzakiri, Hanif. Islam dan Pembebasan, Jakarta: Djambatan dan PENA, 2000.

\footnotetext{
${ }^{43}$ Ibid, 269-285.
} 
Dhakiri, Muh. H., Paulo Freire, Islam, dan pembebasan, Jakarta: Djambatan dan penerbit Pena, 2002.

Fadli, Rizky Very. “Tinjauan Filsafat Humanisme: Studi Pemikiran Paulo Freire Dalam Pendidikan," Reforma: Jurnal Pendidikan dan Pembelajaran, Vol. 9, No.2 (2020): 96-123.

Fakih, Mansour, Roem Topatimasang, Toto Rahardjo, Peny. Pendidikan Popular: Membangun Kesadaran Kritis, Yogyakarta: Pustaka Belajar, 2000.

Freire, Paulo. Pendidikan Sebagai Praktek Pembebasan, Terjemahan Alois A. Nugroho, Jakarta: PT Gramedia,1984.

Freire, Paulo. Pendidikan Kaum Tertindas, Terjemahan Tim Redaksi LP3ES, cet. 7, Jakarta: LP3ES, 2011.

Freire, Paulo. Politik Pendidikan, Kekuasaan dan Pembebasan, Penerjemah: Agung Prihantoro dan Fuad A. Fudiyartanto, cet.6, Jakarta: Pustaka Pelajar, 2007.

Freire, Paulo \& Faundes, A. Belajar Bertanya, Pendidikan Yang Membebaskan, Jakarta: Gunung Mulia, 1995.

Groome, Thomas H. Christian Religious Education. Pendidikan Agama Kristen: Berbagi Cerita dan Visi Kita, Jakarta: BPK Gunung Mulia, 2011.

Hutabarat, Oditha R. "Pedagogi Hati: Model Pak Sebagai Pendidikan Politik Bagi Warga Gereja Di Indonesia," Voice of Wesley: Jurnal Ilmiah Musik dan Agama, Vol. 2, No.1 (2018)

Musta'anu, Al. Pandangan Pendidikan Islam Terhadap Teori Konsientisasi Paulo Freire, Thesis, Program Pascasarjana, IAIN Sunan Ampel Surabaya, 2006.

Pusat Pembinaan dan Pengembangan Bahasa, Kamus Besar Bahasa Indonesia, Jakarta: Balai Pustaka, cet-10, 1999.

Rachman, Budi M. Islam Pluralis: Wacana Kesetaraan Kaum Beriman, cet.1 (Jakarta: PARAMADINA), 2001.

Rohinah, Rohinah. "Re-Konsientisasi dalam Dunia Pendidikan (Membangun Kesadaran Kritis melalui Pemikiran Paulo Freire)," Tarbiyah: Jurnal Ilmiah Kependidikan, Vol. 8, No.1 (2019), 1-12

Seymour, Jack L., Memetakkan Pendidikan Kristen, Pendekatan-pendekatan Menuju Pembelajaran Jemaat, Jakarta: BPK Gunung Mulia, 2016.

Smith, William A. Konsientisasi, Yogyakarta: Kanisius, 2004.

Yunus, Firdaus M. Pendidikan Berbasis Realitas social; Paulo Freire \& Y.B. Mangunwijaya, Jogjakarta: Logung Pustaka, 2005. 